\title{
Short-term variation in air quality associated with firework event: A case study
}

\author{
KHAIWAL RAVINDRA *, SUMAN MOR and C.P. KAUSHIK \\ Department of Environmental Science and Engineering, Guru Jambheshwar \\ University, Hisar-125001 (India).
}

\begin{abstract}
:
The effect of fireworks on the air quality was assessed from the ambient concentrations of various air pollutants $\left(\mathrm{SO}_{2}, \mathrm{NO}_{2}, \mathrm{PM}_{10}\right.$ and TSP) during Diwali festival in Hisar city (India), in November 1999. The extensive use of fireworks was found to be related with short-term variation in air quality. During the festival the concentration of $\mathrm{SO}_{2}$ was observed to be increased $\sim 10$ - fold at few sites, whereas the concentrations of $\mathrm{NO}_{2}, \mathrm{PM}_{10}$ and TSP increased 2-3 times, compared to the data collected on a typical winter day in December 1999. The maximum $\mathrm{NO}_{2}$ concentration was observed a day after the festival. The diurnal pattern of the above pollutants showed a slight increase in the night. The levels of these pollutants observed during Diwali were found to be moderately high, which can be associated with serious health impacts.
\end{abstract}

Key words: Air pollution, Diwali Festival, fireworks, $\mathrm{SO}_{2}, \mathrm{NO}_{2}, \mathrm{PM}_{10}, \mathrm{TSP}$.

*Corresponding Author: Present Address: Ravindra, Micro and Trace Analysis Center, Department of Chemistry, University of Antwerp, Universiteitsplein 1, B-2610, Antwerp, Belgium.e-mail: khaiwal.ravindra@ua.ac.be or khaiwal@yahoo.com 


\section{Introduction:}

Diwali, or Deepawali, is a festival of "rows of light", which is celebrated every year during October/November in India. Celebrating with the illumination and fireworks brings gaiety, joy and festivity. Fireworks contains, chemical such as arsenic, sulphur, manganese, sodium oxalate, aluminium and iron dust powder, potassium perchlorate, strontium nitrate, barium nitrate and charcoal ${ }^{1}$. Burning of fireworks release pollutants, like sulphur dioxide $\left(\mathrm{SO}_{2}\right)$, carbon dioxide $\left(\mathrm{CO}_{2}\right)$, carbon monoxide $(\mathrm{CO})$, suspended particles (including particles below 10 $\mu \mathrm{m}$ in diameter, i.e. $\mathrm{PM}_{10}$ ) and several metals like aluminium, manganese and cadmium, etc., which are associated with serious health hazards ${ }^{2-4}$. Additionally, firecrackers often result in serious accidents and lethal injuries ${ }^{5}$.

High concentrations of $\mathrm{Mn}$ and $\mathrm{Cr}$ have been reported in the scalp hair of manufacturers of fireworks ${ }^{6}$. Firework related trace elements have also been found in blood and urine of victims of firework disasters ${ }^{7}$. Carranza et al. ${ }^{8}$ have also reported significant increase in $\mathrm{Mg}$ and $\mathrm{Al}$ in aerosol particles related with fireworks. Fleischer et al. ${ }^{9}$ reported that remains of fireworks contained toxic equivalent quantity (TEQ) of octachlorinated dioxins and furans up to $142 \mathrm{ng} / \mathrm{kg}$, as well as hexachlorobenzene in the range of 0.05 to $1400 \mathrm{mg} / \mathrm{kg}$. In Oxford (England), an increase in dioxin and furan concentrations (TEQ) by a factor of four occurred during the period of bonfire night, suggesting that bonfire and /or fireworks can be a significant source of trace organic pollutants ${ }^{10}$. The complex nature of particulate with trace metals and organic compounds possess more threat to human health according to a recent review ${ }^{11}$. The use of coloured fireworks generates ozone at the ground level, which is a strong and harmful oxidizing agent ${ }^{12}$. The use of coloured sparklers by people, mostly children at ground level, put them at high risk of inhaling the emitted pollutants. 
Excess emergency hospital admissions have been reported during Diwali festival related to burn hazards and increased asthma attacks. Particulate matter and the sulphur oxides aggravate the conditions of asthma and bronchitis ${ }^{13-14}$. Studies ${ }^{15-16}$ on the short-term exposure to high pollution concentration suggest a higher prevalence of bronchitis, asthma, and other symptoms,

and hence, found to be related with the increase in emergency room visit in hospitals ${ }^{17-20}$. Trapping of pollutants, due to atmospheric inversion under cold conditions during Diwali, promotes the formation of smog that stays close to the ground for long time before its dispersion into the atmosphere. Smog may worsen the condition of patients with lung, heart and nervous system diseases.

The objective of present study is to assess the short-term variation in the ambient concentration of $\mathrm{SO}_{2}$, nitrogen dioxide $\left(\mathrm{NO}_{2}\right)$, total suspended particles (TSP) and $\mathrm{PM}_{10}$ associated with firework events at different location in Hisar city during Diwali festival, in the year 1999 , from $5^{\text {th }}$ to $9^{\text {th }}$ of November. The health effects of short-term exposure to these pollutants have been discussed. To assess the daily variations in air quality, the diurnal pattern was also studied. Finally the ambient air quality was compared with that of a typical winter day of December 1999.

\section{Experimental}

A total of four sampling sites were selected in Hisar city $\left(29^{\circ} 10^{\prime} \mathrm{N}, 75^{\circ} 46^{\prime}\right.$ E, 215.2 meter above mean sea level) on the bases of differential population characteristics (Fig. 1). The district civil hospital (CHP) was selected as sensitive area, and three different residential locations selected were, Sector-13 (S13), which represent densely populated with moderately financially rich population, Guru Jambheshwar University (GJU), primarily institutional and partially residential area and the Sector-15 (S15) densely populated area with mostly financially 
rich population. Characteristics of population with varying financial status, likely indicate their, spending capacity to celebrate this very paramount Indian festival. Financially strong population generally spend more money on firework as the festival is deeply connected with strong human sentiments.

APM-460 respirable dust samplers (RDS) with provision for gaseous sampling APM-411 (Envirotech, New Delhi) was used for measuring the concentrations of TSP, $\mathrm{PM}_{10}, \mathrm{NO}_{2}$ and $\mathrm{SO}_{2}$ in the air. The sampling inlet was placed $\sim 5$ meter above the ground level, because most of the houses have enough roof space and they generally use this roof space for display of fireworks. Further this height can be considered as the respirable zone for people stayed in 2-3 storey buildings. The APM-460 Respirable Dust Sampler was equipped with a cyclone. The cyclone was designed by Envirotech to provide separation of $\mathrm{PM}_{10}$ particles. Atmospheric air was drawn through the cyclone and $20 \times 25 \mathrm{~cm}$ glass fibre filter (GFF) paper sheet at a flow rate of 0.8 to $1.2 \mathrm{~m}^{3} \mathrm{~min}^{-1}$.

As the air with suspended particulate enters the cyclone, coarse non-respirable dust is separated from the air stream by centrifugal forces. The suspended particulate matter falls through the cyclone's conical hopper and gets collected in the cyclonic-cup. The fine dust comprising the respirable fraction of TSP passes through the cyclone and gets collected on the GFF paper. The amount of non-respirable particulate (NRP) and respirable particulate per unit volume of air passed was calculated on the basis of the difference between initial and final weights of the cyclone cup and that of the GFF paper, and the total volume of the air sucked during sampling. Mass concentration of TSP was calculated by adding the concentration of $\mathrm{PM}_{10}$ and NRP, i.e. $\left[\mathrm{TSP}\left(\mu \mathrm{g} / \mathrm{m}^{3}\right)=\mathrm{PM}_{10}\left(\mu \mathrm{g} / \mathrm{m}^{3}\right)+\mathrm{NRP}\left(\mu \mathrm{g} / \mathrm{m}^{3}\right)\right]$. For gaseous $\left(\mathrm{SO}_{2}\right.$ and $\left.\mathrm{NO}_{2}\right)$ sampling the impingers were exposed in two shift of 12 hours at an impingement rate of $1 \mathrm{dm}^{3}$ 
$\min ^{-1}$ to get two samples for day and night concentration. $\mathrm{SO}_{2}$ was analysed following Lodge ${ }^{21}$ by employing the West-Gaeke method on Spectronic-21 spectrophotometer at wavelength of 560 nm. $\mathrm{NO}_{2}$ was also analyzed following Lodge ${ }^{21}$ employing the Jacob-Hochheiser modified method on the above spectrophotometer at wavelength of $540 \mathrm{~nm}$.

\section{Results and Discussion}

Burning of sulfur nitrates, magnesium, aluminium, paper and host of other materials contained in crackers and fireworks produces air pollution during Diwali. The full composition and the relative concentration of the various gaseous vapours and particulate pollutants emitted is not known. However, $\mathrm{SO}_{2}, \mathrm{NO}_{2}$, and particulate matter (specially $\mathrm{PM}_{10}$ ) are of special interest, as they are known to be potentially injurious to the respiratory passages and other health effcets ${ }^{3,17}$.

The metrological parameters during Diwali and after Diwali are presented in Table 1, which shows that the metrological conditions during both monitoring periods were almost identical and can be used for the comparison of the air quality data. Further the atmosphere was stable with no inversion, which support a low lapse rate. During the monitoring period the weather was sunny with out any clouds cover. NE \& NNE were the prevailing wind directions recorded.

\section{Sulphur dioxide}

In general, firecrackers contain $75 \%$ potassium nitrate, $15 \%$ carbon $(\mathrm{C})$, and $10 \%$ sulfur (S). Potassium nitrate is a strong oxidising agent, when burnt with $\mathrm{C}$ and $\mathrm{S}$, it release gases such as $\mathrm{CO}_{2}$ and $\mathrm{SO}_{2}$. The site-specific daily average concentration of $\mathrm{SO}_{2}$ before Diwali varied from $6.4 \mu \mathrm{g} / \mathrm{m}^{3}$ (S13) to $27 \mu \mathrm{g} / \mathrm{m}^{3}$ (GJU). The reason for the high concentration of $\mathrm{SO}_{2}$ in the university area seems to be related with the pre-Diwali celebrations by the students before leaving the campus for Diwali holidays. During Diwali, the $\mathrm{SO}_{2}$ concentration increased up to 
ten times $\left(36.1 \mu \mathrm{g} / \mathrm{m}^{3}\right)$ at $\mathrm{S} 15$ site and increased approximately four times $\left(14.5 \mu \mathrm{g} / \mathrm{m}^{3}\right)$ at S13 site to its concentration during a typical winter day ${ }^{22}$ (Table 2) of 1999, where as at GJU $\mathrm{SO}_{2}$ concentration of $35.9 \mu \mathrm{g} / \mathrm{m}^{3}$ was observed. A day after Diwali the $\mathrm{SO}_{2}$ concentration decreased significantly, as compared to the levels on Diwali (Fig. 2). At the sensitive site, $\mathrm{SO}_{2}$ concentration increased slightly $\left(7.6 \mu \mathrm{g} / \mathrm{m}^{3}\right)$ during Diwali as compared to $6.4 \mu \mathrm{g} / \mathrm{m}^{3}$ a day before Diwali. Diurnal pattern of $\mathrm{SO}_{2}$ concentration showed a slight increase in night (6 p.m. to 6 a.m.) as compared to daytime (Table 3), which seems to be associated with increased firework events during the night (a special characteristic of Diwali night). Although the daily average $\mathrm{SO}_{2}$ concentration during winter season remains well below the maximum allowed limit ${ }^{23}$ for different areas (Table 4), it seems to be moderately high during Diwali.

High levels of $\mathrm{SO}_{2}$ are particularly dangerous in the presence of particulate matter, because it slowly adsorbs on fine atmospheric particles and can be transported very deep into lungs, and therefore staying there for a long time. Due to their very long residence time and acidic character they can cause serious damage to the lungs tissue (Oedema). $\mathrm{WHO}^{24}$ and other studies $^{25}$ have shown that of among the particles of diverse composition, sulphates have the worst health impact, which also stay in air for long time.

Gong, et al. ${ }^{16}$ studied the short-term health response to $\mathrm{SO}_{2}$ exposure on asthmatic patients. They found that ten minute $\mathrm{SO}_{2}$ exposure at concentration $>1.32 \mathrm{mg} / \mathrm{m}^{3}$ and ventilation $30 \mathrm{dm}^{3} /$ min can cause short term asthma manifestations more intense than those usually experienced from everyday stress with out $\mathrm{SO}_{2}$ exposure. Many other studies ${ }^{18,24}$ have reported the short-term exposure to $\mathrm{SO}_{2}$ causes broncho-constriction. Most of the information on the acute effects of $\mathrm{SO}_{2}$ comes from controlled chamber experiments on volunteers exposed to $\mathrm{SO}_{2}$ for period ranging from a few minutes up to one hour ${ }^{26}$. Acute responses occur within the first few 
minutes after commencement of inhalation. Normally healthy individuals show upper respiratory symptoms, whereas asthmatics and person with respiratory hyper-reactivity exhibit acute responses. The effect in sensitive individuals includes in reduction in mean forced expiratory volume over one second $\left(\mathrm{FEV}_{1}\right)$, reduction in forced vital capacity (FVC) and increases in specific airway resistance (sRAW), and symptoms, such as wheezing, or shortness of breathing. These effects are enhanced by exercises that increase the volume of air inspired, as it allows $\mathrm{SO}_{2}$ to penetrate into the respiratory $\operatorname{tract}^{27}$ of the lungs.

\section{Nitrogen dioxide}

A day before Diwali, the daily average concentration of $\mathrm{NO}_{2}$ ranged from 14.1 $\mu \mathrm{g} / \mathrm{m}^{3}$ (GJU) to $21.3 \mu \mathrm{g} / \mathrm{m}^{3}$ (CHP). On Diwali, the maximum $\mathrm{NO}_{2}$ concentration was noted at S13 $\left(34.1 \mu \mathrm{g} / \mathrm{m}^{3}\right)$, followed by S15 $\left(23.3 \mu \mathrm{g} / \mathrm{m}^{3}\right)$, CHP $\left(22.9 \mu \mathrm{g} / \mathrm{m}^{3}\right)$, and GJU $\left(17.0 \mu \mathrm{g} / \mathrm{m}^{3}\right)$. On Diwali, two to three times increase in $\mathrm{NO}_{2}$ concentration was observed at the various site, compared to that of a typical winter day concentration. Even a day after Diwali, the daily average $\mathrm{NO}_{2}$ concentration showed an increasing trend (Fig. 3) and the maximum concentration of $\mathrm{NO}_{2}$ was observed at S15 $\left(48.3 \mu \mathrm{g} / \mathrm{m}^{3}\right)$ site, followed by S13 $\left(41.9 \mu \mathrm{g} / \mathrm{m}^{3}\right)$, GJU $\left(33.2 \mu \mathrm{g} / \mathrm{m}^{3}\right)$ and CHP $\left(26.3 \mu \mathrm{g} / \mathrm{m}^{3}\right)$ sites. During monitoring period, the diurnal pattern for $\mathrm{NO}_{2}$ concentration also showed a slight increase in the night, as compare to daytime (Table 3). During Diwali period, the daily average $\mathrm{NO}_{2}$ concentrations remained close to the maximum prescribed limit in comparison to the typical winter day.

Most effects of $\mathrm{NO}_{2}$ are exerted in the airways and the lungs. The health effects of $\mathrm{NO}_{2}$

have been reviewed in various studies ${ }^{26,28-30} . \mathrm{NO}_{2}$ is a deep lung irritant, which has been shown to generate biochemical alterations and histological demonstrable lung damage in laboratory animals as a result of both acute and chronic exposure ${ }^{24}$. $\mathrm{NO}_{2}$ increases bronchial reactivity, as 
measured by the response of normal and asthmatic subjects following exposure to pharmacological broncho-constrictor agents, even at levels that do not affect pulmonary function directly in the absence of broncho-constrictor. Some authors have shown increased responsiveness to broncho-constrictors at $\mathrm{NO}_{2}$ levels as low as 376 to $565 \mu \mathrm{g} / \mathrm{m}^{3}$, other found that higher level had no such effect ${ }^{26}$. Ponka et al. ${ }^{31}$ have found a significant association with emergency room visit for exacertation of chronic bronchitisor emphysema, and low levels of air pollutants specifically with $\mathrm{SO}_{2}$ and $\mathrm{NO}_{2}$. Inhaled $\mathrm{NO}_{2}$ can penetrate to small lung airways and hence, there is much greater susceptibility with $\mathrm{SO}_{2}$ to broncho-constrictive response in individuals with asthma ${ }^{32,33}$.

\section{Respirable $\left(\mathrm{PM}_{10}\right)$ and total suspended particles}

Concentration of $\mathrm{PM}_{10}$ at all the sites exceeded the maximum prescribed allowable limit before and after Diwali. During Diwali a slight increase in $\mathrm{PM}_{10}$ concentration was observed to its pre Diwali concentration. The maximum daily average concentration of $\mathrm{PM}_{10}$ was observed at S15 $\left(224 \mu \mathrm{g} / \mathrm{m}^{3}\right)$ site followed by S13 $\left(221 \mu \mathrm{g} / \mathrm{m}^{3}\right)$, CHP $\left(143 \mu \mathrm{g} / \mathrm{m}^{3}\right)$ and GJU $\left(110 \mu \mathrm{g} / \mathrm{m}^{3}\right)$ monitoring stations. A slight fall in $\mathrm{PM}_{10}$ concentration was observed a day after the festival (Fig. 4). Even on a typical day of winter, the level of particles was reported to be very high in Hisar city (Table 2), which seems to be related with the fact that it has semi desert climate with less vegetation cover and fine soil structure ${ }^{22}$. The higher concentration of $\mathrm{PM}_{10}$ in inhaled air has more possibility of these particles to reach deep in lungs. Entry of particles into lungs is dangerous, because they can carry a complex mixture of toxic pollutants from fireworks. Michie et al. ${ }^{34}$ have also studied effect of $\mathrm{PM}_{10}$ particles on paediatric respiratory diseases following community fireworks. There are reports on the decrements in peak expiratory flow rates in children, in relation with $\mathrm{PM}_{10}$ concentration ${ }^{35}$. 
Reviews and analysis of epidemiological literature for acute adverse effects following exposure to particulates have been presented by Pope et al. ${ }^{36}$ Schwartz et al. ${ }^{37}$ Dockery et al. ${ }^{38}$ and other teams ${ }^{39}$ estimate these effects as percent increase in mortality associated with each incremental increase of $\mathrm{PM}_{10}$ by $10 \mu \mathrm{g} / \mathrm{m}^{3}$ (Table 5). Individuals, who were elderly or had preexisting lung, or heart disease, appeared to be more susceptible than others to adverse effects of $\mathrm{PM}_{10}$. During Diwali period, concentration of suspended particles in air has been found to be double to its concentration on a typical winter day, although the meteorological conditions were very similar. Clark ${ }^{40}$, has also reported a dramatically short term (hourly average) increase in the particle level, which originated from bonfires and fireworks across England and Wales. Further the $\mathrm{PM}_{10}$ levels were strongly influenced by local conditions, i.e. how close the sites were to large bonfires, and weather changes.

TSP concentration exceeded the maximum prescribed limits at all the sites (Table 3). Before Diwali, the daily average concentration ranged from $268 \mu \mathrm{g} / \mathrm{m}^{3}$ (GJU) to $473 \mu \mathrm{g} / \mathrm{m}^{3}$ (S13). On Diwali the maximum concentration of $542 \mu \mathrm{g} / \mathrm{m}^{3}$ was noted at S15 (Fig 5). The TSP concentration at Diwali was approximately double of the maximum prescribed limit, i.e. 200 $\mu \mathrm{g} / \mathrm{m}^{3}$ for residential area. After Diwali the TSP concentration slightly decreased. Babu et al. ${ }^{41}$ have also observed a large increase in the black carbon concentration by a factor of over 3 above the unperturbed background level at a remote costal location, associated with the Diwali festival in 2000 .

The diurnal pattern for the concentrations of TSP and $\mathrm{PM}_{10}$ does not show significant changes during day and night (Table 2). In general, the particle concentration seems to be doubled during Diwali festival. Exposure to particulate matter can aggravate chronic respiratory and cardiovascular diseases, alter host defence, damage lung tissue, lead to premature death and 
possibly contribute to cancer. TSP and specifically $\mathrm{PM}_{10}$, or smaller particles have been related to premature death, aggravated asthma, increased hospital admission, and increased respiratory problems $^{14,39,42}$.

\section{Conclusions}

Display of fireworks with loud explosive, crackers, etc., during Diwali celebration causes enormous though short-lived air pollution. The $\mathrm{SO}_{2}, \mathrm{NO}_{2}, \mathrm{PM}_{10}$ and TSP concentrations shown increase, as the crackers start bursting. Concentration of $\mathrm{SO}_{2}$ at Diwali increased many times, while the level of other pollutants also got approximately doubled to their normal concentration reported during a typical winter day. Highest concentration of pollutants was noted at S15, which seems to be related with the economic status of the citizens of that locality and dense population. The short-term exposure of these pollutants above the permissible allowable limits can increase the likelihood of acute health effects. Hence, there is a need exist to determine this proportion and to control this pollution. Further this scientific study also corroborate the general feeling of creating a strong public opinion to celebrate festival like Diwali, New Year etc. in an environmentally friendly manner.

\section{Acknowledgement}

The authors would like to acknowledge Dr. Bhatiya (Civil Hospital), Mr. Sandal (Sector-13) and Mr. Mor (Sector-15) and their family for allowing to use the instruments in their premises and for their kind support. 


\section{References:}

1 H.H. Holmes, Encyclopedia Americana, 1983, Vol-11, p. 263

2 W. Bach, A. Daniels, L. Dickinson, F. Hertlein, J. Morrow, S. Margolis, V.D. Dinh, Int. J. Environ. Stud., 1975, 7, 183.

3 S.A. Takiguchi, R. Kusumoto, N. Teruya, S.A. Mayers, M.H. Yu, Crit. Care Med., 2000, 28, 527.

4 J.M. Becker, S. Iskandrian, J. Conkling, J. Ann. Allerg. Asthma I.M., 2000, 85,512.

5 M. J. Bull, P. Agran, H.G. Gardner, D. Laraque, S.H. Pollack, G.A. Smith, H.R. Spivak, M. Tenenbein, Pediatrics, 2001, 108, 190.

6 A. Sukumar, R. Subramanian, Sci. Total Environ., 1992, 114, 161.

7 P. Fischer, Epidemiology, 2001, 12, S98-S98.

8 J.E. Carranza, B.T. Fisher, G.D. Yoder, D.W. Hahan, Spectrochim. Acta B, 2001, 56, 851.

9 O. Fleischer, H. Wichmann, W. Lorenz, Chemosphere, 1999, 39, 925.

10 P. Dyke, P. Coleman, R. James, Chemosphere, 1997, 34, 1191.

11 Ravindra, A.K. Mittal. R. Van Grieken, Rev. Environ. Health, 2001, 16, 169.

12 A. K. Attri, U. Kumar, V. K. Jain, Nature, 2001, 411, 1015.

13 D.V. Bates, R. Sizto, Environ. Res., 1987, 43, 317.

14 D.V. Bates, Thorax, 1996, 51, S3-S8.

15 B. Brunekreef, D.W. Dockery, M. Krzyzanowski, Environ. Health. Persp., 1995, 103, 3.

16 H. Gong, P.A. Lachenbruch, P. Harber, W.S. Linn, Toxicol. Ind. Health, 1995, 11, 467.

17 D.V. Bates, Scand. J. Work Environ. Health, 1995, 21, 405.

18 J.R. Balmes, J.M. Fine, D. Sheppard, Am. Rev. Respir. Dis., 1987, 136, 1117. 
19 S. Walters, R.K. Griffiths, J.G. Ayres, Thorax, 1994, 49, 133.

20 B. Bakke, B. Ulvestad, P. Stewart, M.B. Lund, W. Eduard, Scand. J. Work Environ. Health, 2001, 27, 250.

21 J.P. Lodge, Methods of air sampling and analysis, $3^{\text {rd }}$ edn, Lewes Publisher INC, Chelsea, Michigan, 1989, pp. 403-406.

22 Ravindra, M.Tech. Dissertation, G.J. University, Hisar, 1999.

23 Central Pollution Control Board (CPCB), 2000 'National ambient air quality statistics of India', Parevesh Bhavan, Delhi.

24 WHO, Air quality Guidelines for Europe, WHO regional Publications, Europien Series No. 23, Regional Office for Europe, World Health Organization, Copenhagen, 1987.

25 D.W. Dockery, J. Schwartz, D. Spengler, Environ. Res., 1993, 59, 362.

26 WHO, Air quality Guidelines for Europe, WHO regional Publications, Europien Series No. 23, Regional Office for Europe, World Health Organization, Copenhagen, 1999. (http://www.who.dk)

27 D. Schwela, Rev. Environ. Health, 2000, 15, 13.

28 WHO, Nitrogen Oxides. Environmental Health Criteria 188, World Health Organization, Genewa, 1997.

29 A.J. Chauhan, M.T. Krishna, A.J. Frew, Rev. Environ. Health, 1998, 13, 91.

30 U. Ackermann-liebrich, R. Rapp. In: S.T. Holgate, J.M. Samet, H.S. Koren, R.L. Maynard, eds. Air pollution and health. London, Academic Press, 1999, pp. 559-584.

31 A. Ponka, M. Virtanen, Environ. Res., 1994, 65, 207.

32 C. Schindler, U. Ackermann-Liebrich, P. Leuenberger, C. Monn, R. Rapp, G. Bologini et al., Epidemiology, 1998 9, 405. 
33 WHO, Guideline for air quality, World Health Organization, Genewa, 2000. (http://www.who.int/peh/)

34 C.A. Michie, G. Keeling, J. Freeman, Paediatrics, 2000, 47, 479A.

35 G. Hoek, D.W. Dockery, A. Pope, L. Neas, W. Roemer, B. Brunkreef, Eur. Respir. J., 1998, 11, 1307.

36 C. Pope, J. Schwartz, M. Ransom, Arc. Environ. Health, 1992, 47, 211.

37 J. Schwartz, Am. J. Epidemiol., 1993, 137, 1136.

38 D. Dockery, C.I. Pope, X. Xiping, J. Spengler, J. Wore, M. Fay, B. Ferris, F. Speize, New Eng. J. Med., 1993, 329, 1753.

39 Committees of the Environmental and Occupational Health Assembly (COEHA) of the American Thoracic Society. Am. J. Respir. Crit. Care Med. 1996, 131, 133.

$40 \quad$ H. Clark, Atmos. Environ, 1997, 31, 2893.

41 S.S. Babu, K.K. Moorthy, Curr. Sci. India, 2001, 81, 1208.

42 A. Seaton, W. MacNee, K. Donaldson, D. Godden, Lancet 1995, 345, 176. 
Table 1: Meteorological parameters recorded during and after Diwali.

\begin{tabular}{lll}
\hline Meteorological parameters & During Diwali* & After Diwali* \\
\hline Max. Temperature $\left({ }^{0} \mathrm{C}\right)$ & $32.8 \pm 2.8$ & $27.9 \pm 0.7$ \\
Min. Temperature $\left({ }^{0} \mathrm{C}\right)$ & $12.4 \pm 3.5$ & $6.0 \pm 0.7$ \\
Vapour Pressure $(\mathrm{Hg} \mathrm{mm})$ & & \\
Morning & $10.8 \pm 1.8$ & $7.9 \pm 0.1$ \\
Evening & $7.9 \pm 1.3$ & $7.0 \pm 0.0$ \\
Relative Humidity $(\%)$ & & \\
Morning & $66.3 \pm 4.2$ & $87.5 \pm 6.4$ \\
Evening & $23.2 \pm 4.2$ & $27.0 \pm 1.4$ \\
Mean Wind Velocity & & \\
(km/h) & $3.6 \pm 1.4$ & $1.5 \pm 0.7$ \\
Sunshine Hours & $7.9 \pm 0.8$ & $7.8 \pm 0.5$ \\
Evaporation (mm) & $4.9 \pm 0.8$ & $2.5 \pm 0.2$ \\
Rainfall (mm) & $0.0 \pm 0$ & $0.0 \pm 0$ \\
& & \\
& &
\end{tabular}

*Average with Standard deviation. 
Table 2: Average (24 hours) ambient concentrations $\left(\mu \mathrm{g} / \mathrm{m}^{3}\right)$ of pollutants in Hisar city during a typical winter day of Dec. 1999.

\begin{tabular}{|c|c|c|c|c|}
\hline Sites & $\mathrm{SO}_{2}$ & $\mathrm{NO}_{2}$ & $\mathbf{P M}_{10}$ & TSP \\
\hline $\mathrm{CHP}+\mathrm{GJU}$ & $<4$ & 15 & $122 *$ & $313^{*}$ \\
\hline $\mathrm{S} 15+\mathrm{S} 13$ & $<4$ & 20 & $103 *$ & $282 *$ \\
\hline
\end{tabular}


Table 3: Diurnal pattern of various air pollutants during Diwali festival.

\begin{tabular}{|c|c|c|c|c|c|c|c|c|c|c|c|c|c|}
\hline \multirow[t]{2}{*}{ Pollutant } & & \multicolumn{3}{|c|}{ CIVIL HOSPITAL } & \multicolumn{3}{|c|}{ SECTOR-13 } & \multicolumn{3}{|c|}{ G.J.University } & \multicolumn{3}{|c|}{ SECTOR -15 } \\
\hline & & Night & Day & $24 \mathrm{hrs}^{\otimes}$ & Night & Day & $24 \mathrm{hrs}^{\otimes}$ & Night & Day & $24 \mathrm{hrs}^{\otimes}$ & Night & Day & $24 \mathrm{hrs}^{\otimes}$ \\
\hline \multirow{3}{*}{$\mathrm{SO}_{2}$} & $\begin{array}{l}\text { Pre- } \\
\text { Diwali }\end{array}$ & 6.1 & 6.8 & $6.5 \pm 0.5$ & 8.7 & 4.2 & $6.5 \pm 3.2$ & 48.0 & 4.6 & $26.3 \pm 30.7$ & 10.9 & 3.5 & $7.2 \pm 5.2$ \\
\hline & Diwali & 10.3 & 4.9 & $7.6 \pm 3.8$ & 17.6 & 11.4 & $14.5 \pm 4.4$ & 60.6 & 11.1 & $35.9 \pm 35$ & 63.1 & 9.0 & $36.1 \pm 38.3$ \\
\hline & $\begin{array}{l}\text { Post- } \\
\text { Diwali }\end{array}$ & 6.5 & 8.1 & $7.3 \pm 1.1$ & 5.4 & 5.3 & $5.4 \pm 0.1$ & 15.3 & 12.9 & $14.1 \pm 1.7$ & 11.3 & 9.8 & $10.6 \pm 1.1$ \\
\hline \multirow{3}{*}{$\mathrm{NO}_{2}$} & $\begin{array}{l}\text { Pre- } \\
\text { Diwali }\end{array}$ & 18.0 & 24.5 & $21.1 \pm 4.6$ & 25.7 & 15.8 & $20.8 \pm 7.0$ & 18.2 & 10.0 & $14.1 \pm 5.8$ & 24.6 & 14.6 & $19.6 \pm 7.1$ \\
\hline & Diwali & 20.0 & 25.7 & $22.9 \pm 4.0$ & 43.0 & 25.5 & $34.2 \pm 12.4$ & 17.0 & 17.0 & $17.0 \pm 0$ & 28.6 & 18.0 & $23.3 \pm 7.5$ \\
\hline & $\begin{array}{l}\text { Post- } \\
\text { Diwali }\end{array}$ & 20.2 & 32.5 & $26.5 \pm 8.7$ & 35.7 & 48.0 & $41.9 \pm 8.7$ & 41.0 & 25.1 & $33.1 \pm 11.2$ & 37.7 & 58.9 & $48.3 \pm 15$ \\
\hline \multirow{3}{*}{$\mathrm{PM}_{10}$} & $\begin{array}{l}\text { Pre- } \\
\text { Diwali }\end{array}$ & 129.4 & 171.5 & $150.5 \pm 29.8 *$ & 187.1 & 123.0 & $155.1 \pm 45.3^{*}$ & 112.2 & 55.4 & $83.7 \pm 40.3$ & 190.1 & 116.1 & $153.1 \pm 52.3 *$ \\
\hline & Diwali & 169.0 & 116.8 & $142.9 \pm 36.9 *$ & 306.1 & 136.4 & $221.2 \pm 120 *$ & 115.0 & 104.9 & $110 \pm 7.1 *$ & 332.3 & 114.9 & $223.6153 .7 *$ \\
\hline & $\begin{array}{l}\text { Post- } \\
\text { Diwali }\end{array}$ & 160.0 & 153.5 & $156.7 \pm 4.6^{*}$ & 205.1 & 197.6 & $201.3 \pm 6.0 *$ & 149.2 & 114.1 & $131.7 \pm 24.8^{*}$ & 149.6 & 213.2 & $181.4 \pm 45^{*}$ \\
\hline \multirow{3}{*}{ TSP } & $\begin{array}{l}\text { Pre- } \\
\text { Diwali }\end{array}$ & 241.9 & 351.6 & $296.8 \pm 77.6^{*}$ & 493.2 & 452.7 & $473 \pm 28.6^{*}$ & 238.9 & 296.5 & $267.7 \pm 40.7 *$ & 392.8 & 412.3 & $402.6 \pm 13.8^{*}$ \\
\hline & Diwali & 465.2 & 433.7 & $449.4 \pm 22.3 *$ & 517.3 & 509.7 & $514 \pm 5.5^{*}$ & 269.9 & 362.1 & $316 \pm 65.2^{*}$ & 664.6 & 421.5 & $543 \pm 172 *$ \\
\hline & $\begin{array}{l}\text { Post- } \\
\text { Diwali }\end{array}$ & 394.7 & 368.6 & $381.7 \pm 18.5^{*}$ & 427.1 & 404.9 & $416 \pm 15.7 *$ & 268.4 & 334.8 & $301.6 \pm 47 *$ & 308.9 & 492.9 & $400.9 \pm 130 *$ \\
\hline
\end{tabular}

*Exceeds permissible limits, ${ }^{\otimes} 24$ hrs average with Standard deviation Night: 6 pm to 6 am.

Day: 6 am to $6 \mathrm{pm}$.
Pre-Diwali $=24$ hrs before Diwali

Diwali $=$ The night and the following day.

Post-Diwali $=24$ hrs after Diwali. 
Table 4: National ambient air quality standards ${ }^{23}$.

\begin{tabular}{lccc}
\hline & \multicolumn{3}{c}{ Concentration in ambient air $\left(\mu \mathrm{g} / \mathbf{m}^{\mathbf{3}}\right) *$} \\
\cline { 2 - 4 } Pollutant & $\begin{array}{c}\text { Sensitive } \\
\text { area }\end{array}$ & $\begin{array}{c}\text { Industrial } \\
\text { area }\end{array}$ & Residential area \\
$\mathrm{SO}_{2}$ & 30 & 120 & 80 \\
$\mathrm{NO}_{2}$ & 30 & 120 & 80 \\
$\mathrm{TSP}$ & 100 & 500 & 200 \\
$\mathrm{PM}_{10}$ & 75 & 150 & 100 \\
\hline
\end{tabular}


Table 5: Combined effect estimates of daily mean particulate pollution ${ }^{42}$.

Health Impacts

Change (\%) in health indicator per each

$10 \mu \mathrm{g} / \mathrm{m}^{3}$ increase in $\mathbf{P M}_{10}$

Increase in daily mortality
a. Total deaths
1.0
b. Respiratory deaths
3.4
c. Cardiovascular deaths
1.4

Increase in hospital usage

(all respiratory diagnoses)

$\begin{array}{ll}\text { a. Admissions } & 1.4 \\ \text { b. Emergency department visits } & 0.9\end{array}$

Exacerbation of asthma
a. Asthmatic attacks
3.0
b. Bronchodilator use
12.2
c. Emergency department visit
3.4
d. Hospital admissions
1.9

Increase in respiratory symptom report
a. Lower respiratory
3.0
b. Upper respiratory
0.7
c. Cough
2.5

Decrease in lung function
a. Forced expiratory
0.15
b. Peak expiratory flow
0.08 


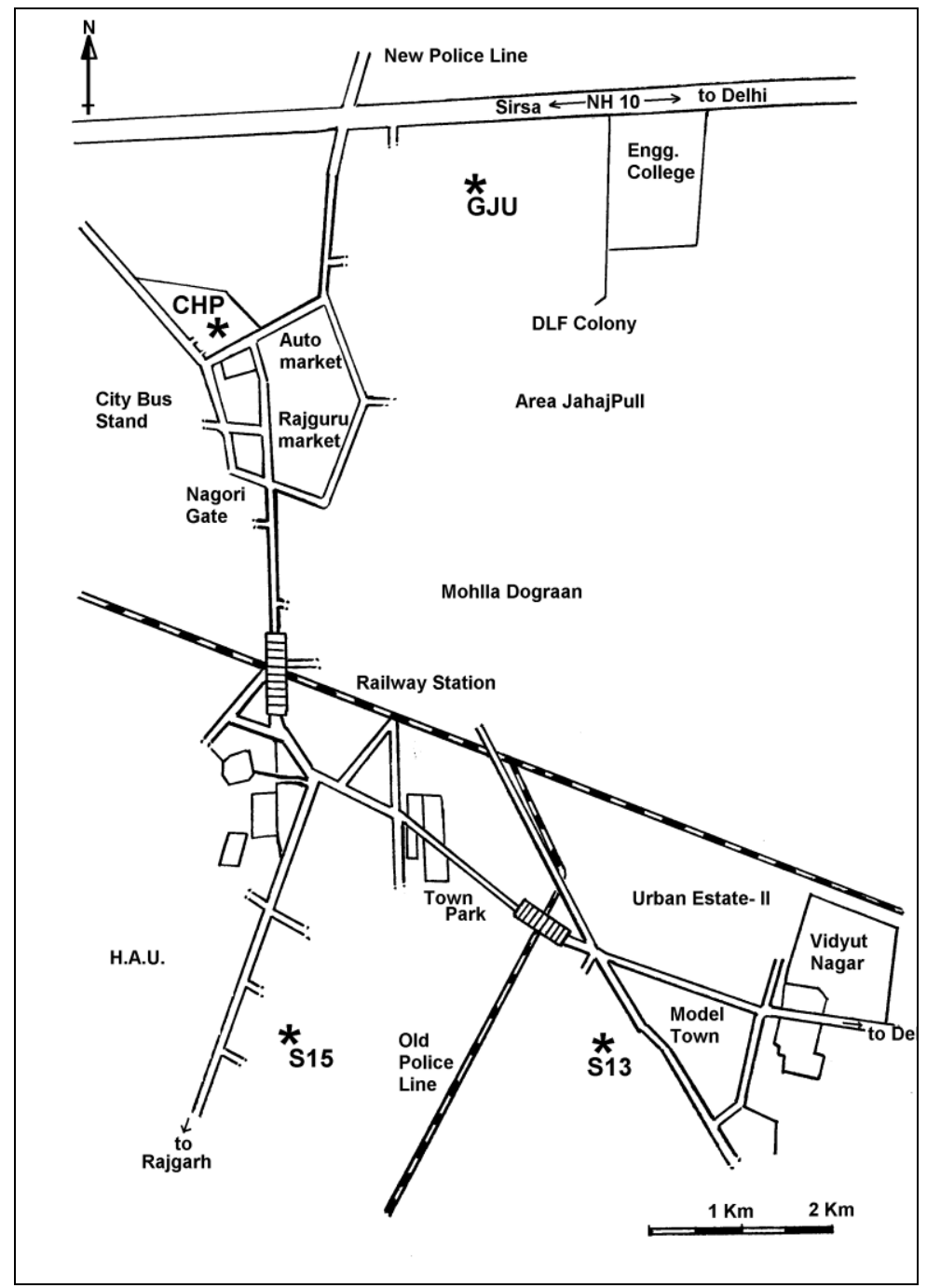

Figure 1: Sketch map of sampling sites in Hisar city. 


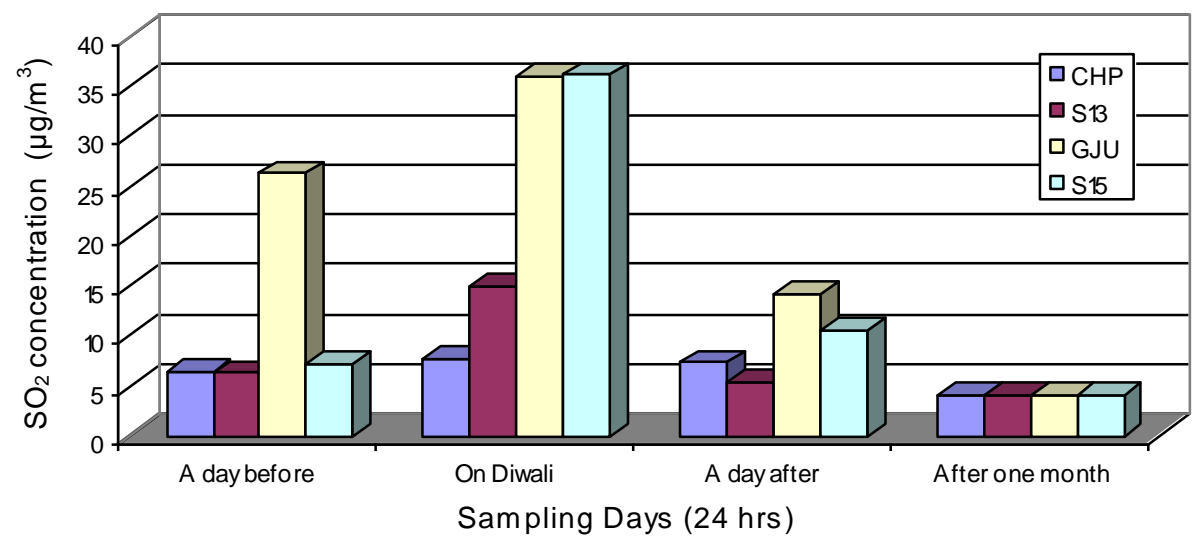

Figure 2: Variation in $\mathrm{SO}_{2}$ concentration during Diwali festival

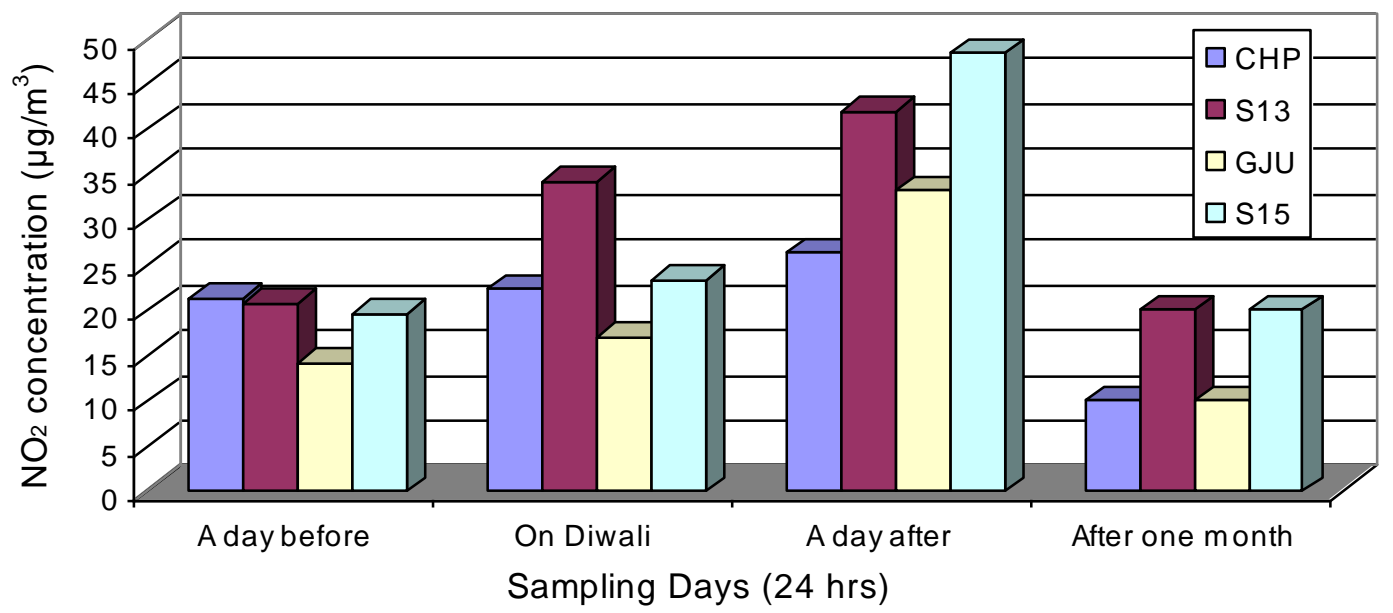

Figure 3: Variation in $\mathrm{NO}_{2}$ concentration during Diwali festival 


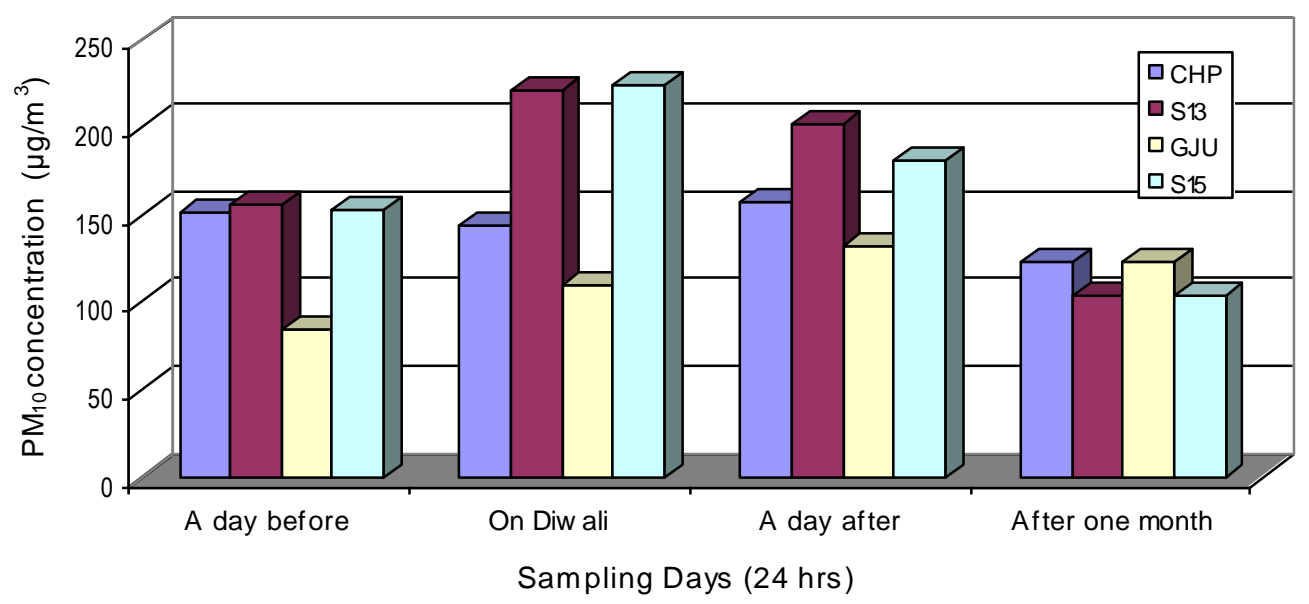

Figure 4: Variation in $\mathrm{PM}_{10}$ concentration during Diwali festival.

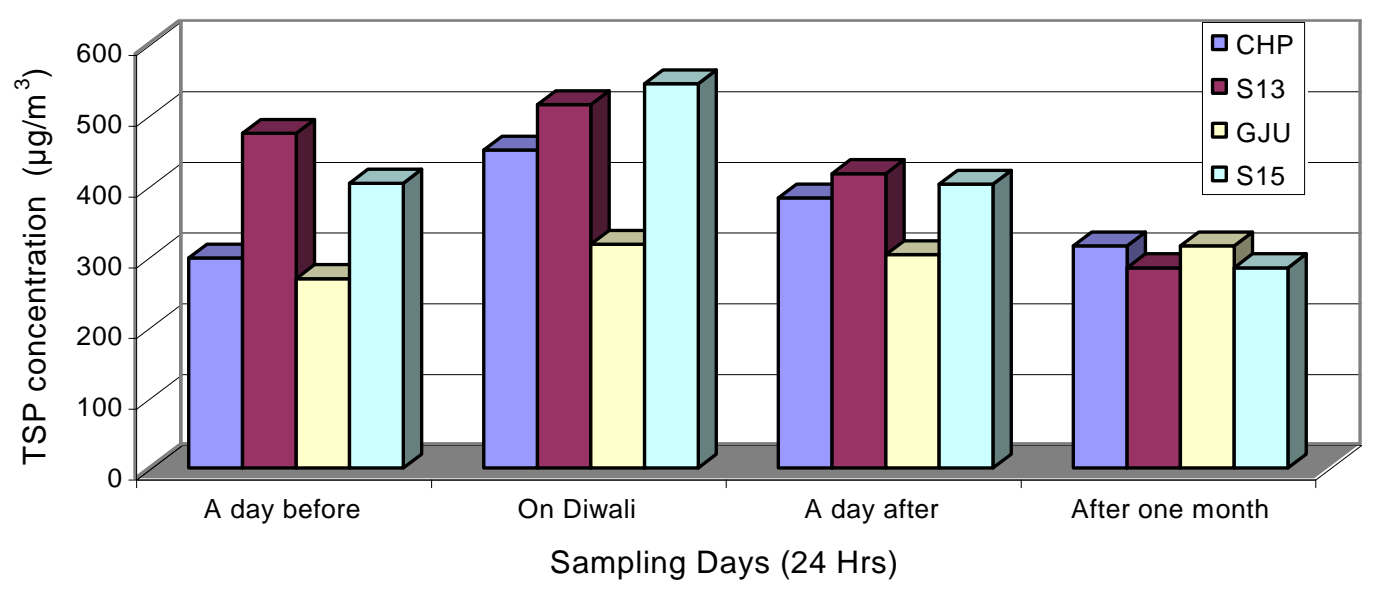

Figure 5: Variation in TSP concentration during Diwali festival. 